\title{
Identification, molecular characterization and factors associated with occurrences of Cryptosporidium spp. in calves on dairy farms in Brazil
}

\author{
Identificação, caracterização molecular e fatores associados à ocorrência de \\ Cryptosporidium spp. em bezerros de propriedades leiteiras no Brasil
}

Juliana Silva de Oliveira1* (D); Felippe Danyel Cardoso Martins'; Winni Alves Ladeia'; Isadora de Britto Cortela; Manuela Ferraz Valadares'; Andressa Maria Rorato Nascimento de Matos' ${ }^{1}$; Eloiza Teles Caldart ${ }^{1}$; Henderson Ayres ${ }^{2}$; Italmar Teodorico Navarro'; Roberta Lemos Freire ${ }^{1}$

${ }^{1}$ Departamento de Medicina Veterinária Preventiva, Universidade Estadual de Londrina - UEL, Londrina, PR, Brasil ${ }^{2}$ MSD Saúde Animal, São Paulo, SP, Brasil

How to cite: Oliveira JS, Martins FDC, Ladeia WA, Cortela IB, Valadares MF, Matos AMRN et al. Identification, molecular characterization and factors associated with occurrences of Cryptosporidium spp. in calves on dairy farms in Brazil. Braz J Vet Parasitol 2021; 30(4): e009621. https://doi.org/10.1590/S1984-29612021094

\begin{abstract}
Cattle are an important source of zoonotic species of Cryptosporidium for humans. The aim of this study was to investigate the presence of Cryptosporidium, identify the species and determine the risk factors relating to environment, animals and management among dairy calves in eight Brazilian states. A total of 408 fecal samples from calves aged 1-60 days were analyzed. An epidemiological questionnaire was completed. Sample screening was performed using Ziehl-Neelsen technique and the positive samples were subjected to nested PCR. Cryptosporidium species were identified by means of the PCR-RFLP technique, using SSPI, ASEI and MBOII enzymes. The Ziehl-Neelsen technique showed that $89.7 \%$ (35/39) of the farms and $52.9 \%$ (216/408) of the samples were positive. Through nested PCR, these protozoa were detected in $54.6 \%$ of the samples. The 56 samples subjected to PCR-RFLP presented Cryptosporidium parvum. There was higher prevalence of the parasite in animals aged 7 to 28 days (62.6\%). Diarrhea, ages between seven and 28 days and a spring water source were factors associated with the risk of infection. The calf hutch-type management system was associated with reduced infection. These findings demonstrate the high level of Cryptosporidium spp. circulation in cattle herds and the predominance of the species C. parvum.
\end{abstract}

Keywords: Risk factors, Cryptosporidium parvum, dairy cattle, Brazil.

\begin{abstract}
Resumo
O gado é uma fonte importante de espécies zoonóticas de Cryptosporidium para o homem. O objetivo deste estudo foi investigar a presença de Cryptosporidium, identificar a espécie e determinar os fatores de risco relacionados ao meio ambiente, aos animais e ao manejo em bezerros leiteiros em oito estados brasileiros. Um total de 408 amostras fecais de bezerros, com idade entre 1 e 60 dias, foram analisadas. Um questionário epidemiológico foi preenchido. A triagem das amostras foi realizada pela técnica de Ziehl-Neelsen, e as amostras positivas foram submetidas à "nested" PCR. As espécies de Cryptosporidium foram identificadas pela técnica de PCR-RFLP, utilizando-se as enzimas SSPI, ASEI e MBOII. A técnica de Ziehl-Neelsen mostrou que 89,7\% (35/39) das fazendas e $52,9 \%$ (216/408) das amostras foram positivas. Por meio de nested PCR, esses protozoários foram detectados em 54,6\% das amostras. As 56 amostras submetidas à PCR-RFLP apresentaram Cryptosporidium parvum. Houve maior prevalência do parasita em animais de 7 a 28 dias $(62,6 \%)$. Diarreia, idade entre sete e 28 dias, e fonte de água mineral foram fatores associados ao risco de infecção. O sistema de manejo do tipo "casinha" para bezerros foi associado à redução da infecção. Esses achados demonstram o alto nível de Cryptosporidium spp. em circulação nos rebanhos bovinos e o predomínio da espécie C. parvum.
\end{abstract}

Palavras-chave: Fatores de risco, Cryptosporidium parvum, bovinos de leite, Brasil. 


\section{Introduction}

Cryptosporidium spp. are the causative agents of cryptosporidiosis, an important zoonosis that affects both humans and animals, with worldwide distribution (Chalmers \& Davies, 2010). Their oocysts are highly resistant to environmental conditions and disinfectants, including chlorine and most compounds used for water treatment (Duhain et al., 2012). This resistance allows these protozoa to remain viable for long periods in the environment and in water (Thompson et al., 2008).

Nearly 40 species of Cryptosporidium are known and about 20 of them have been reported in humans, among which Cryptosporidium hominis and Cryptosporidium parvum are responsible for most infections (Ryan et al., 2014; Khan et al., 2018; Ryan et al., 2018). Several species of Cryptosporidium have been found verified in cattle, but C. parvum, Cryptosporidium andersoni, Cryptosporidium bovis and Cryptosporidium ryanae have been most frequently identified. Cattle are important reservoirs for these parasites, contributing to environmental contamination and can host the zoonotic species C. parvum (Xiao, 2010; Holsback et al., 2018).

Cryptosporidium parvum mainly affects cattle between one and three weeks of age (Langoni et al., 2004; Cruvinel et al., 2020). However, animals older than one month and adults can also be affected by other species of Cryptosporidium (Meireles, 2010; Toledo et al., 2017; Díaz et al., 2021). Infection occurs via the fecal-oral route, either directly or indirectly (Ryan et al., 2014). Humans and animals become infected through direct contact with infected people and animals (Xiao, 2010), or through contact with manure, contaminated water or contaminated food (Mawly et al., 2015). Animals affected by cryptosporidiosis develop diarrhea, dehydration and growth retardation, and their condition may progress to severe enteritis or even to death (Fayer et al., 1990).

The rate of occurrence of cryptosporidiosis is usually higher in dairy cattle due to the intensive rearing system, which favors contact between animals and increases transmission of the parasite (Martins-Vieira et al., 2009). In Brazil, its prevalence ranges from 3\% to 64\% (Feitosa et al., 2004; Oliveira et al., 2007; Sevá et al., 2010; Meireles et al., 2011; Silva et al., 2011; Lima et al., 2013; Silva et al., 2013; Coelho et al., 2016; Toledo et al., 2017; Holsback et al.,-2018; Cruvinel et al., 2020). Most of these studies were conducted in states where herds are mainly composed of dairy cattle, i.e. in Rio Grande do Sul, Paraná, Santa Catarina, Minas Gerais and Goiás (IBGE, 2017). The presence of this parasite in herds leads to significant economic losses, including the cost of treatment; reduced feed conversion with consequent lower growth rate; lower production; and losses due to animal death (Gunn \& Stott, 1997; Jacobson et al., 2018).

The objective of this study was to evaluate the presence and identify the species of Cryptosporidium in dairy calves in herds in eight Brazilian states and determine possible factors associated with infection.

\section{Material and Methods}

\section{Sampling and epidemiological questionnaire}

From July 2016 to June 2017, 408 fecal samples were obtained from calves aged between one and 60 days. These samples were received from 39 dairy cattle farms, from a total of 40,612 animals that were symptomatic or asymptomatic regarding diarrhea. All of these farms had a history of diarrhea in young calves. The farms were located in 33 municipalities in eight states in the southern, southeastern, northeastern and central-western regions of Brazil. The states selected for this survey account for $80 \%$ of the country's milk production (IBGE, 2017).

Animals on these farms were selected randomly and feces were obtained from the selected animals by a veterinarian, taken directly from the rectum using sterile plastic gloves. These samples were stored at $4{ }^{\circ} \mathrm{C}$. An epidemiological questionnaire was completed by a person who was responsible for the herd on each farm. This contained questions relating to the environment (water source; and different species in the same place); management (husbandry system for cows and calves; dairy feeding systems; weaning age; and milk supply); sanitary and reproductive management (quarantine; herd replacement; and reproductive system); characteristics of the animals (age and sex); and samples sent (characteristics of the animals' feces).

\section{Staining, storage and diagnosis}

The samples were screened using the modified Ziehl-Neelsen technique (Henriksen \& Pohlenz, 1981) on fecal smears, which were then read under an optical microscope with 40x objective lens. Samples that were positive for the presence of Cryptosporidium spp. were classified according to the number of oocysts, such that one cross 
meant up to three oocysts observed per slide; two crosses meant up to five oocysts per field; three crosses meant five to 10 oocysts per field; and four crosses meant more than 10 oocysts per field (Robert et al., 1990). Afterwards, positive samples were placed in $2 \mathrm{~mL}$ microtubes and stored at $-20^{\circ} \mathrm{C}$.

\section{DNA extraction}

All Ziehl-Neelsen-positive samples were subjected to further molecular analysis, in which DNA was directly extracted from fecal samples using a commercial kit (NucleoSpin Tissue ${ }^{\circledR}$, Macherey-Nagel, Düren, Germany). This was done following the protocol recommended by the manufacturer for fecal samples, but with the addition of three cycles of freezing $\left(-80^{\circ} \mathrm{C}\right.$ for $10 \mathrm{~min}$ ) and thawing $\left(56^{\circ} \mathrm{C}\right.$ for $5 \mathrm{~min}$ ) before the lysis step, in order to promote rupture of the oocysts (Wells et al., 2015).

\section{Nested Polymerase Chain Reaction (nPCR)}

Fragments of interest from the 18SSU rRNA gene, containing 823 to 840 base pairs, were amplified using nested PCR (nPCR). The following mixture was used in the first reaction: 1x Invitrogen ${ }^{\circledR}$ PCR buffer; $200 \mu \mathrm{M}$ of dNTPs; $2.5 \mathrm{mM}$ of $\mathrm{MgCl}_{2} ; 400 \mathrm{nM}$ of each primer (forward and reverse); $1.25 \mathrm{U}$ of Platinum ${ }^{\circledR}$ Taq DNA polymerase; $400 \mathrm{ng}$ of nonacetylated bovine serum albumin (BSA); $2.0 \mu \mathrm{L}$ of extracted DNA; and ultrapure water to complete the volume up to $25 \mu \mathrm{L}$. The product of the first reaction was diluted in $50 \mu \mathrm{L}$ of ultrapure water to prepare for the second reaction. In the second reaction, the forward primer 5'-GGAAGGGTTGTATTTATTAGATAAAG-3' and the reverse primer 5'-AAGGAGTAAGGAACAACCTCCA-3' were used, following the same protocol used in the first reaction. The amplification conditions for both reactions were as follows: 5 minutes at $95^{\circ} \mathrm{C}$, followed by 35 cycles of $45 \mathrm{~s}$ at $94{ }^{\circ} \mathrm{C}$ (denaturation), $45 \mathrm{~s}$ at $55^{\circ} \mathrm{C}$ (annealing), $60 \mathrm{~s}$ at $72{ }^{\circ} \mathrm{C}$ (extension) and 5 minutes at $72{ }^{\circ} \mathrm{C}$ (final extension) (Xiao et al., 2001). Ultrapure water was used as a negative control, and C. parvum DNA was used as a positive control.

The nPCR products were subjected to electrophoresis on 1.5\% agarose gel (Agarose, LGC Biotechnology) stained with SYBR Safe ${ }^{\circledR}$ (SYBR Safe, Invitrogen, Waltham, MA, USA). The bands were read in a photodocumenter under ultraviolet light excitation.

\section{PCR-RFLP}

To characterize Cryptosporidium species, samples that were found to be positive through nPCR, with the degree of positivity in the Ziehl-Neelsen technique of three or four crosses, were selected for the restriction fragment length polymorphism (RFLP) technique. The enzymes used to cleave the product from the second nPCR reaction were SSPI, ASEI and MBOII (Feng et al., 2007; Xiao et al., 1999). The reactions were carried out using a mixture of $5 \mu \mathrm{L}$ of the DNA product, $1 \mathrm{X}$ NEB® buffer, $5 \mathrm{U}$ of the restriction enzymes SSPI and MBOII, $6 \mathrm{U}$ of the enzyme ASEI and ultrapure water to make up a total volume of $20 \mu \mathrm{L}$. The cleavage time was two hours at $37^{\circ} \mathrm{C}$ and 15 minutes at $65^{\circ} \mathrm{C}$, for enzyme inactivation. Afterwards, the reactions were subjected to electrophoresis on $2.5 \%$ agarose gel stained with SYBR Safe ${ }^{\circledR}$ and were photodocumented. Subsequently, the band patterns obtained were compared with images contained in the Cryptodb database (http://www.cryptodb.org).

\section{Statistical analysis}

For the purpose of screening the variables for entry into the simple and multiple logistic regression model, bivariate exploratory analysis was performed using Yates-corrected chi-square or Fisher's exact tests. The significance level used for selecting variables for the multiple model was $20 \%$. With these selected variables, the final model was obtained by means of multiple logistic regression analysis with a significance level of $5 \%$. For the univariate and multivariate analyses, the Epilnfo ${ }^{\mathrm{TM}}$ epidemiological and statistical package (version 7.2.2.6; CDC, Atlanta) was used, and the strength of the association was estimated by means of odds ratios (ORs) and their respective $95 \%$ confidence intervals (CI).

\section{Results}

Out of all the 408 samples, Cryptosporidium was detected in $52.9 \%$ (216/408) of the samples screened. The parasite was found on $89.7 \%$ (35/39) of the farms. Among the samples that were found to be positive through screening with the Ziehl-Neelsen technique, molecular analysis was done using nPCR and 54.6\% (118/216) of them presented Cryptosporidium DNA (Figure 1). 


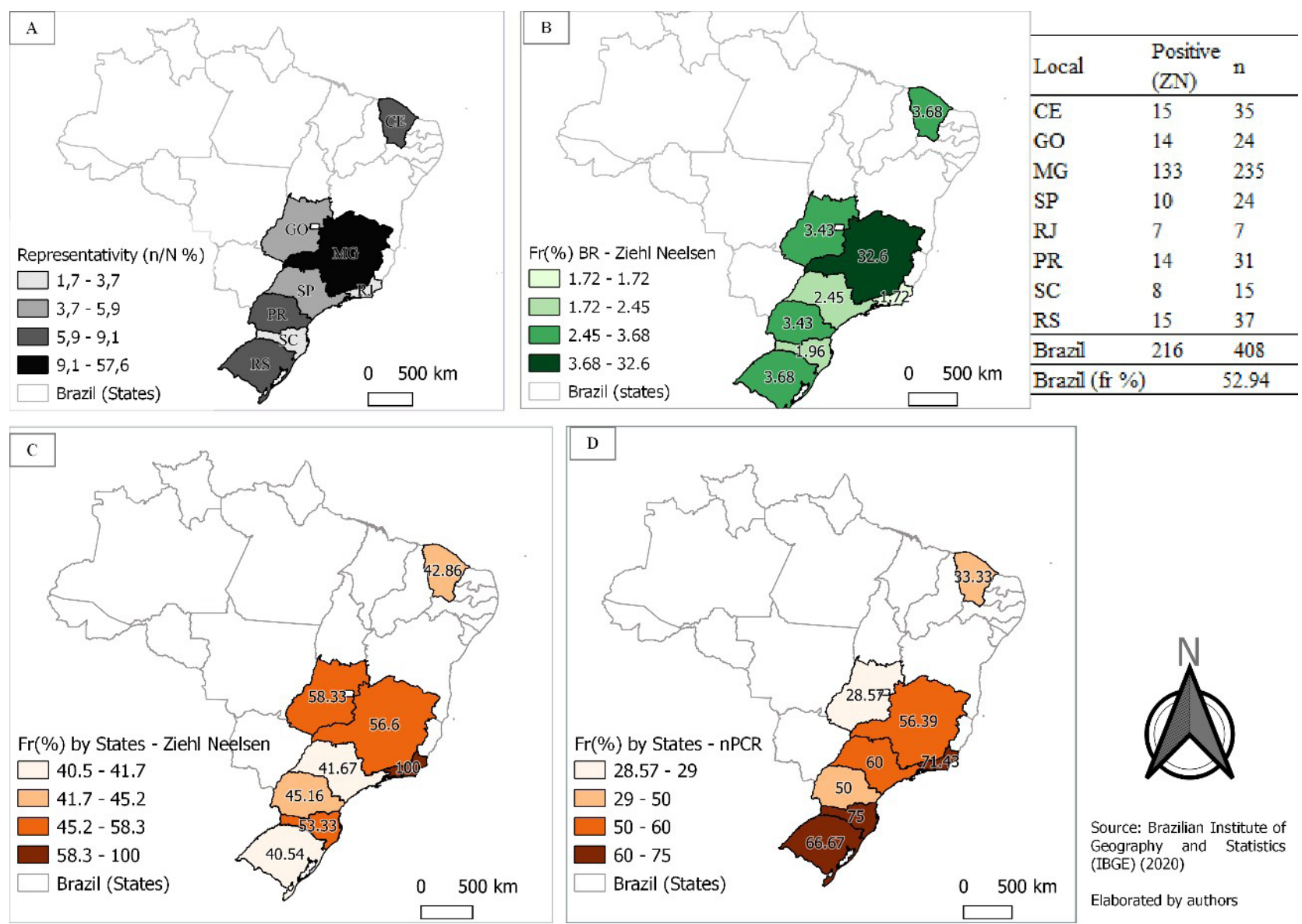

Figure 1. Frequency of Cryptosporidium spp. in dairy calves with diarrhea in Brazil and its states, diagnosed by means of ZiehlNeelsen and nPCR, from July 2016 to June 2017. Note: A - Map of Brazil showing the relative representativity of $n$ fecal samples according to its states, considering $\mathrm{N}$ to be the total number of samples collected. $\mathrm{B}$ - Map of Brazil showing the frequency of Cryptosporidium spp. in fecal samples through Ziehl-Neelsen diagnosis, relative to all samples obtained in the country, organized according to its states. C - Map of Brazil showing the frequency of Cryptosporidium spp. in fecal samples through Ziehl-Neelsen diagnosis, relative to its states. D - Map of Brazil showing the frequency of Cryptosporidium spp. in fecal samples through nPCR diagnosis, relative to its states. States: CE - Ceará; GO - Goiás; MG - Minas Gerais; SP - São Paulo; RJ - Rio de Janeiro; PR - Paraná; SC - Santa Catarina; RS - Rio Grande do Sul.

Regarding the locations of the farms, the samples originated predominantly from the southeastern and southern regions, which accounted for $56.4 \%$ and $33.3 \%$ of the farms analyzed, respectively. The average herd size was 1,041 ( $\pm 1,057$; range $80-4,200$ ); $78.9 \%$ of the farms reported having milk production greater than 250 liters/day; and on $82.0 \%$ of them the weaning age was between 60 and 90 days. In $74.4 \%$ of the farms, new animals inserted into the herd had origin in the own farm. Also on $74.4 \%$ of the farms, use of an artesian well as a source of water for the animals was reported. Among the calves, $71.5 \%$ of them were aged between seven and 28 days, and $86.1 \%$ were female. Presence of diarrhea was described in $53.7 \%$ of the animals (Table 1 ).

Among the variables analyzed from the epidemiological questionnaire applied, a spring water source, diarrhea, age between 7 and 28 days and the production system were factors associated with the presence of Cryptosporidium (Table 2).

Among the $118 \mathrm{nPCR}$-positive samples, 56 were selected for characterization of the Cryptosporidium species by means of the RFLP technique, according to the degree of positivity in the Ziehl-Neelsen technique (three or four crosses). All the samples analyzed were compatible with C. parvum.

\section{Discussion}

This study demonstrated that Cryptosporidium is present in many Brazilian states, with overall frequencies similar to or higher than in other studies around the world (Cruvinel et al., 2020; Holsback et al., 2018; Toledo et al., 
Table 1. Simple logistic regression analysis on the association of exposure variables with presence of Cryptosporidium spp. oocysts, evaluated using the Ziehl-Neelsen technique, in fecal samples from calves on dairy farms in eight states in Brazil (samples collected from July 2016 to June 2017).

\begin{tabular}{|c|c|c|c|}
\hline Exposition Variables & $\begin{array}{l}\text { Positive Samples/Total } \\
(\%)\end{array}$ & OR (CI95\%) & $p$-value \\
\hline \multicolumn{4}{|l|}{ Region } \\
\hline Southeast & $150 / 266(56.4)$ & - & 0.150 \\
\hline South & 37 / 83 (44.6) & - & \\
\hline Northeast & 15 / 35 (42.8) & - & \\
\hline Midwest & 14 / 24 (58.3) & - & \\
\hline \multicolumn{4}{|l|}{ Milk Production } \\
\hline Up to 50 liters / day & 27 / 56 (48.2) & - & 0.563 \\
\hline >250 liters / day & 180 / 337 (53.2) & - & \\
\hline \multicolumn{4}{|l|}{ Age Range } \\
\hline $0-17$ days* & 25 / 107 (23.4) & 1 & \\
\hline 7-|28 days & 174 / $278(62.6)$ & $5.2(3.3-9.1)$ & $<0.001$ \\
\hline$>28$ days & $3 / 4$ (75.0) & - & - \\
\hline \multicolumn{4}{|l|}{ Gender } \\
\hline Female & 180 / $330(54.5)$ & $1.3(0.7-2.4)$ & 0.394 \\
\hline Male & 25 / 53 (47.2) & & \\
\hline \multicolumn{4}{|l|}{ Diarrhea } \\
\hline Yes & 134 / $212(63.2)$ & $2.5(1.7-3.8)$ & $<0.001$ \\
\hline No & 73 / 183 (39.9) & & \\
\hline \multicolumn{4}{|l|}{ Calves Production System } \\
\hline Little house* & $64 / 144(44.4)$ & 1 & \\
\hline Collective & $71 / 121$ (58.6) & $1.8(1.1-2.9)$ & 0.028 \\
\hline Chain & $70 / 119$ (58.8) & $1.8(1.1-2.9)$ & 0.027 \\
\hline \multicolumn{4}{|l|}{ Water Source - Spring } \\
\hline Yes & $94 / 148$ (63.5) & $1.9(1.3-2.9)$ & 0.001 \\
\hline No & 122 / 260 (46.9) & & \\
\hline \multicolumn{4}{|c|}{ Water Source Stream / River / Weir / Dam } \\
\hline Yes & $72 / 138(52.1)$ & $0.9(0.6-1.4)$ & 0.906 \\
\hline No & 144 / $270(53.3)$ & & \\
\hline \multicolumn{4}{|l|}{ Water Source - Shallow well } \\
\hline Yes & $4 / 4(100.0)$ & - & 0.164 \\
\hline No & 212 / $404(52.5)$ & & \\
\hline \multicolumn{4}{|l|}{ Water Source -Artesian Well } \\
\hline Yes & 175 / $325(53.8)$ & $1.1(0.7-1.9)$ & 0.547 \\
\hline No & $41 / 83(49.4)$ & & \\
\hline
\end{tabular}

*Reference category.

2017; Coelho et al., 2016; Delafosse et al., 2015; Díaz-Lee et al., 2011). The variations in the frequencies observed between the studies may be associated with age, sample size, management practices, study design or different diagnostic techniques (Hatam-Nahavandi et al., 2019).

In the present study, all the farms analyzed reported having presence of diarrhea in their dairy herds and, when evaluated for the presence of Cryptosporidium, 89.7\% (35/39) of the farms showed a positive result. Although it is not possible to conclude that on these farms, Cryptosporidium was the only causative agent of diarrhea, we would 
Table 2. Final model of multiple logistic regression analysis on variables that were statistically associated $(P<0.05)$ with the presence of Cryptosporidium spp. oocysts in 408 fecal samples from calves on dairy farms in eight states in Brazil (samples collected from July 2016 to June 2017).

\begin{tabular}{|c|c|c|}
\hline \multirow{2}{*}{$\begin{array}{l}\text { Cryptosporidium spp. } \\
\text { Exposition Variables }\end{array}$} & \multicolumn{2}{|c|}{ Final Multiple Logistic Regression Model } \\
\hline & $p$-value & Adjusted OR $(95 \% \mathrm{CI})$ \\
\hline \multicolumn{3}{|l|}{ Water Source - Spring } \\
\hline No* & & 1 \\
\hline Yes & 0.0000 & $4.19(2.40-7.29)$ \\
\hline \multicolumn{3}{|l|}{ Diarrhea } \\
\hline No* & & 1 \\
\hline Yes & 0.0000 & $2.85(1.76-4.61)$ \\
\hline \multicolumn{3}{|l|}{ Age range } \\
\hline $0-17$ days* & & 1 \\
\hline 7- $\mid 28$ days & 0.0000 & $10.25(5.48-19.16)$ \\
\hline >28 days & 0.0118 & $23.41(2.01-272,13)$ \\
\hline \multicolumn{3}{|l|}{ Calves Production System } \\
\hline Calf hutch* & & 1 \\
\hline Collective & 0.4789 & $1.23(0.69-2.20)$ \\
\hline Chain & 0.0280 & $1.93(1.07-3.47)$ \\
\hline Intercept & 0.0000 & \\
\hline
\end{tabular}

*Reference category.

suggest that $C$. parvum may be involved in the appearance of most neonatal diarrhea outbreaks. This is supported by the association between oocyst shedding and presence of diarrhea.

In a study carried out among 207 calves up to seven months of age, Lee et al. (2019) demonstrated the wide variety of etiological agents involved in calf diarrheal conditions. In Brazil, Cruvinel et al. (2020) observed associations between risk factors for Cryptosporidium diarrhea in calves, including the risk of Cryptosporidium infection induced by rotavirus infection and vice versa. In the present study, it was possible to conclude that there was an association between positive samples and the presence of diarrhea in calves. This clinical sign may be associated with the presence of Cryptosporidium itself, which leads to malabsorption due to atrophy of intestinal microvilli, or through association with other agents (Oliveira et al., 2012). Although Cryptosporidium infection is related to the presence of diarrhea, asymptomatic animals can also eliminate oocysts (Conceição et al., 2021), thus playing an important role as a source of environmental contamination (Thomson et al., 2017).

There was no significant association between the presence of Cryptosporidium and the sex of the animals, possibly because there were no differences in management or environment between the two sexes that could cause a difference in the risk of infection. This finding is compatible with studies such as those carried out in France by Delafosse et al. (2015) and in Argentina by Garro et al. (2016).

Animals of different ages are susceptible to cryptosporidiosis. However, the highest infection rate occurs between one and three weeks of age (Santín et al., 2004; Feitosa et al., 2008; Cai et al., 2017; Cruvinel et al., 2020). This was corroborated by the results obtained in the present study, which showed that animals in the range of seven to 28 days old were more frequently infected by Cryptosporidium spp. This age range of risk seems to be related to the fact that the immune system is still developing in this age group. In addition, it may be related to a period during which calves were separated from their mothers at birth and kept under precarious conditions of hygiene, and/or may be due to the presence of adults with subclinical infection, which can maintain the parasite in the environment through constant elimination in feces (Castro-Hermida et al., 2005; Holsback et al., 2018).

The decrease in the quantity of oocysts eliminated with increasing age is associated with maturation of intestinal cells and possible immunity acquired after the animal's first exposure to the parasite (Harp, 2003; Garro et al., 2016). 
It is important to note that cattle of all ages can be infected by the parasite and that adult cattle are generally asymptomatic carriers of some species, given that there have been reports of $C$. parvum in adults and healthy animals (Dessi et al., 2020). In this way, asymptomatic animals can be carriers, thereby contributing to environmental contamination and infection of newborn calves (Martins-Vieira et al., 2009).

In the present study, the production system was a factor associated with infection by Cryptosporidium. When comparing chain and collective systems with calf hutch rearing system, the first two showed a higher chance of presenting positive animals for Cryptosporidium in the bivariate analysis (Table 1) and just the chain system in the multiple logistic regression (Table 2). Probably because calf hutch rearing system prevents agglomeration and consequent increase in contact between animals and large amounts of organic matter. These factors are facilitators for transmission of the parasite. In the calf hutch system, in addition to the animals' segregation from each other, there is a natural barrier formed by the pasture and the exposure of organic matter to sunlight, which can inactivate a portion of the oocysts present in the environment (Walker et al., 2001; Li et al., 2010; Liu et al., 2015). Manyazewal et al. (2018) observed higher prevalence of Cryptosporidium in animals kept in an intensive management system than in animals raised in an extensive system. Maikai et al. (2011) stated that dairy animals under intensive and semi-intensive systems are restricted or confined to a small area, such that they are exposed to contact with other animals and susceptible to infection by the Cryptosporidium parasite. Therefore, systems that increase agglomeration, increase the rate of infectant oocyst elimination to the environment, which raises the risk of infection of other individuals.

Evaluation of the water supply on the farms analyzed showed that water from springs offered higher risk of infection for calves than did water from other sources. This finding corroborates what was reported by Nishi et al. (2009), who reported that the parasite was present in springs on indigenous lands in Paraná; by de Tiyo et al. (2015), who found Cryptosporidium in water from springs that was used for irrigating vegetables; and by Toledo et al. (2017), who detected Cryptosporidium in samples from springs that were used to supply dairy farms. Contamination of spring waters is generally associated with absence of forest and presence of environmental degradation in the surroundings, soil porosity and presence of sewers. Springs located in low parts of the farm, close to pastures or near precarious tanks and plumbing are also at increased risk of contamination (Branco et al., 2012). Vegetation acts as a barrier against the flow of organic matter and prevents erosion and the consequent contamination of water (Andrade et al., 2005).

The species C. parvum was found in $100 \%$ of the samples analyzed by means of PCR-RFLP. This finding may be associated with the age of the animals analyzed, as this species is common in young animals up to two months of age, and its occurrence decreases as the age of the calves increases (Meireles, 2010; Toledo et al., 2017). Other studies conducted worldwide have reported C. parvum as the most frequent species infecting calves up to two months old, with frequencies ranging from 42.2 to $51 \%$ for infected animals (Toledo et al., 2017; Delafosse et al., 2015; Mawly et al., 2015; Smith et al., 2014; Díaz-Lee et al., 2011).

The fact that $C$. parvum was the only species found in the present study does not exclude the possibility of presence of other concomitant parasite species. Some studies have suggested that infections by $C$. bovis and C. ryanae in animals that were severely parasitized by C. parvum may have been masked in the diagnosis because the 18SSU rRNA analysis identifies the genus of the parasite. Consequently, it identifies the predominant species in the sample (Feng et al., 2007; Plutzer \& Karanis, 2009). Increasing age is a limiting factor for C. parvum, but in older animals other Cryptosporidium species can cause subclinical infections (Åberg et al., 2020). C. parvum is the species with the greatest zoonotic potential, and it is one of the most frequent species worldwide, with cattle as an important reservoir for this species (Xiao, 2010).

\section{Conclusion}

Cryptosporidium spp. was widely disseminated in the Brazilian states evaluated. High rates of occurrence of the zoonotic species C. parvum bring a risk of environmental contamination, which increases the likelihood of human infection and outbreaks. Greater attention is needed with regard to management of calves, especially those in the age range of seven to 28 days, and also regarding preservation and protection of water sources and use of calf hutches for reducing the possibility of dissemination of the parasite. 


\section{References}

Åberg M, Emanuelson U, Troell K, Bjorkman C. A single-cohort study of Cryptosporidium bovis and Cryptosporidium ryanae in dairy cattle from birth to calving. Vet Parasitol Reg Stud Rep 2020; 20: 100400. http://dx.doi.org/10.1016/j.vprsr.2020.100400. PMid:32448548.

Andrade J, Sanquetta CR, Ugaya C. Identificação de áreas prioritárias para recuperação da mata ciliar na UHE Salto Caxias. Espaço Energia 2005; (3): 1-8.

Branco N, Leal DAG, Franco RMB. A parasitological survey of natural water springs and inhabitants of a tourist city in southeastern Brazil. Vector Borne Zoonotic Dis 2012; 12(5): 410-417. http://dx.doi.org/10.1089/vbz.2011.0679. PMid:22217166.

Cai M, Guo Y, Pan B, Li N, Wang X, Tang C, et al. Longitudinal monitoring of Cryptosporidium species in pre-weaned dairy calves on five farms in Shangai, China. Vet Parasitol 2017; 241: 14-19. http://dx.doi.org/10.1016/j.vetpar.2017.05.005. PMid:28579024.

Castro-Hermida JA, Delafosse A, Pors I, Ares-Mazás E, Chartier C. Giardia duodenalis and Cryptosporidium parvum infections in adult goats and their implications for neonatal kids. Vet Rec 2005; 157(20): 623-627. http://dx.doi.org/10.1136/vr.157.20.623. PMid:16284331.

Chalmers RM, Davies AP. Minireview: clinical cryptosporidiosis. Exp Parasitol 2010; 124(1): 138-146. http://dx.doi.org/10.1016/j. exppara.2009.02.003. PMid:19545516.

Coelho WMD, Widmer G, Oliveira FP, Amarante AFT, Bresciani KDS. Natural infection by Cryptosporidium spp. in production animals: first description of subtype IlaA15G2R1 in goat kids and piglets in Brazil. Rev Patol Trop 2016; 45(4): 361-368. http:// dx.doi.org/10.5216/rpt.v45i4.44639.

Conceição Al, Almeida LPS, Macedo LO, Mendonça CL, Alves LC, Ramos RAN, et al. Prevalence of infection by Cryptosporidium spp. in calves and associated risk factors in Northeastern Brazil. Arq Bras Med Vet Zootec 2021; 73(1): 34-40. http://dx.doi. org/10.1590/1678-4162-12109.

Cruvinel LB, Ayres H, Zapa DMB, Nicaretta JE, Couto LFM, Heller LM, et al. Prevalence and risk factors for agents causing diarrhea (Coronavirus, Rotavirus, Cryptosporidium spp., Eimeria spp., and nematodes helminthes) according to age in dairy calves from Brazil. Trop Anim Health Prod 2020; 52: 777-791. http://dx.doi.org/10.1007/s11250-019-02069-9. PMid:31591674.

Delafosse A, Chartier C, Dupuy MC, Dumoulin M, Pors I, Paraud C. Cryptosporidium parvum infection and associated risk factors in dairy calves in western France. Prev Vet Med 2015; 118(4): 406-412. http://dx.doi.org/10.1016/j.prevetmed.2015.01.005. PMid:25623968.

Dessì G, Tamponi C, Varcasia A, Sanna G, Pipia AP, Carta S, et al. Cryptosporidium infections in sheep farms from Italy. Parasitol Res 2020; 119(12): 4211-4218. http://dx.doi.org/10.1007/s00436-020-06947-2. PMid:33140165.

Díaz P, Navarro E, Remesar S, García-Dios D, Martínez-Calabuig N, Prieto A, et al. The age-related Cryptosporidium species distribution in asymptomatic cattle from north-western Spain. Animals 2021; 11(2): 256. http://dx.doi.org/10.3390/ani11020256. PMid:33498538.

Díaz-Lee A, Mercado R, Onuoha EO, Ozaki LS, Muñoz V, Martínez FJ, et al. Cryptosporidium parvum in diarrheic calves detected by microscopy and identified by immunochromatographic and molecular methods. Vet Parasitol 2011; 176(2-3): 139-144. http:// dx.doi.org/10.1016/j.vetpar.2010.11.001. PMid:21109352.

Duhain GLMC, Minnaar A, Buys EM. Effect of chlorine, blanching, freezing, and microwave heating on Cryptosporidium parvum viability inoculated on green peppers. J Food Prot 2012; 75(5): 936-941. http://dx.doi.org/10.4315/0362-028x.jfp-11-367. PMid:22564944.

Fayer R, Speer CA, Dubey JP. General biology of Cryptosporidium. In: Dubey JP, Speer CA, Fayer R, editors. Cryptosporidioris of man and animals. 1st ed. Boca Raton: CRS Press; 1990. p. 1-29.

Feitosa FLF, Shimamura GM, Roberto T, Meireles MV, Nunes CM, Ciarlini PC, et al. Prevalência de criptosporidiose em bezerros na região de Araçatuba, Estado de São Paulo, Brasil. Cienc Rural 2004; 34(1): 189-193. http://dx.doi.org/10.1590/S010384782004000100029

Feitosa FLF, Shimamura GM, Roberto T, Mendes LCN, Peiró JR, Féres FC, et al. Importância de Cryptosporidium spp. como causa de diarréia em bezerros. Pesq Vet Bras 2008; 28(10): 452-456. http://dx.doi.org/10.1590/S0100-736X2008001000002.

Feng Y, Ortega Y, He G, Das P, Xu M, Zhang X, et al. Wide geographic distribution of Cryptosporidium bovis and the deer-like genotype in bovines. Vet Parasitol 2007; 144(1-2): 1-9. http://dx.doi.org/10.1016/j.vetpar.2006.10.001. PMid:17097231.

Garro CJ, Morici GE, Utgés ME, Tomazic ML, Schnittger L. Prevalence and risk factors for shedding of Cryptosporidium spp. oocysts in dairy calves of Buenos Aires Province, Argentina. Parasite Epidemiol Control 2016; 1(2): 36-41. http://dx.doi.org/10.1016/j. parepi.2016.03.008. PMid:29988224.

Gunn GJ, Stott AW. A comparison of economic losses due to calf enteritis and calf pneumonia in Scottish beef herds. Epidémiol Santé Anim 1997; 31-32. 
Harp JA. Cryptosporidium and host resistance: historical perspective and some novel approaches. Anim Health Res Rev 2003; 4(1): 53-62. http://dx.doi.org/10.1079/ahrr200352. PMid:12885209.

Hatam-Nahavandi K, Ahmadpour E, Carmena D, Spotin A, Bangoura B, Xiao L. Cryptosporidium infections in terrestrial ungulates with focus on livestock: a systematic review and meta-analysis. Parasit Vectors 2019; 12(1): 453. http://dx.doi.org/10.1186/s13071 019-3704-4. PMid:31521186.

Henriksen SA, Pohlenz JFL. Staining of cryptosporidia by a modified Ziehl-Neelsen technique. Acta Vet Scand 1981; 22(3-4): 594596. http://dx.doi.org/10.1186/BF03548684. PMid:6178277.

Holsback L, Lima HE, Vidotto O, Silva MA, Patelli THC, Martins FDC, et al. Cryptosporidium occurrence in ruminants from the north pioneer mesoregion of Paraná. Rev Bras Parasito/ Vet 2018; 27(2): 248-253. http://dx.doi.org/10.1590/s1984-296120180037. PMid:29924145.

Instituto Brasileiro de Geografia e Estatistica - IBGE. Sistema IBGE de Recuperação Automática - SIDRA [online]. Brasil: IBGE; 2017 [cited 2020 Jan 18]. Available from: https://sidra.ibge.gov.br/pesquisa/ppm/quadros/brasil/2017

Jacobson C, Al-Habsi K, Ryan U, Williams A, Anderson F, Yang R, et al. Crypstosporidium infection is associated with reduced growth and diarrhoea in goats beyond weaning. Vet Parasito/ 2018; 260: 30-37. http://dx.doi.org/10.1016/j.vetpar.2018.07.005. PMid:30197010.

Khan A, Shaik JS, Grigg ME. Genomics and molecular epidemiology of Cryptosporidium species. Acta Trop 2018; 184: 1-14. http:// dx.doi.org/10.1016/j.actatropica.2017.10.023. PMid:29111140.

Langoni H, Linhares AC, Avila FA, Silva AV, Elias AO. Contribution to the study of diarrhea etiology in neonate dairy calves in São Paulo state. J Vet Res Anim Sci 2004; 41(5): 313-319. http://dx.doi.org/10.1590/S1413-95962004000500004.

Lee SH, Kim HY, Choi EW, Kim D. Causative agents and epidemiology of diarrhea in Korean native calves. J Vet Sci 2019; 20(6): e64. http://dx.doi.org/10.4142/jvs.2019.20.e64. PMid:31775191.

Li X, Atwill ER, Dunbar LA, Tate KW. Effect of daily temperature fluctuation during the cool season on the infectivity of Cryptosporidium parvum. Appl Environ Microbiol 2010; 76(4): 989-993. http://dx.doi.org/10.1128/AEM.02103-09. PMid:20023095.

Lima RCA, Aquino MCC, Inácio SV, Viol MA, Zucatto AS, Silveira L No, et al. Caracterização molecular de Cryptosporidium spp. em bezerros (Bos taurus e Bos indicus) no município de Formiga, Minas Gerais - Brasil. Semina: Ciênc Agrár 2013; 34(6): 3747-3754 http://dx.doi.org/10.5433/1679-0359.2013v34n6Supl2p3747.

Liu Y, Dong S, Kuhlenschimdt MS, Kuhlenschmidt TB, Drnevich J, Nguyen TH. Inactivation mechanisms of Cryptosporidium parvum oocysts by solar ultraviolet irradiation. Environ Sci Water Res Technol 2015; 1(2): 188-198. http://dx.doi.org/10.1039/C4EW00079].

Maikai BV, Umoh JU, Kwaga JKP, Lawal IA, Maikai VA, Cama V, et al. Molecular characterization of Cryptosporidium spp. in native breeds of cattle in Kaduna State, Nigeria. Vet Parasito/ 2011; 178(3-4): 241-245. http://dx.doi.org/10.1016/j.vetpar.2010.12.048. PMid:21277091.

Manyazewal A, Francesca S, Pal M, Gezahegn M, Tesfaye M, Lucy M, et al. Prevalence, risk factors and molecular characterization of Cryptosporidium infection in cattle in Addis Ababa and its environs, Ethiopia. Vet Parasitol Reg Stud Rep 2018; 13: 79-84. http:// dx.doi.org/10.1016/j.vprsr.2018.03.005. PMid:30101204.

Martins-Vieira MBC, Brito LAL, Heller L. Oocistos de Cryptosporidium parvum em fezes de bezerro infectado experimentalmente. Arq Bras Med Vet Zootec 2009; 61(6): 1454-1458. http://dx.doi.org/10.1590/S0102-09352009000600030.

Mawly JA, Grinberg A, Velathanthiri N, French N. Cross sectional study of prevalence, genetic diversity, and zoonotic potential of Cryptosporidium parvum cycling in New Zealand dairy farms. Parasit Vectors 2015; 8(1): 240. http://dx.doi.org/10.1186/s13071015-0855-9. PMid:25896433.

Meireles MV, Oliveira FP, Teixeira WFP, Coelho WMD, Mendes LCN. Molecular characterization of Cryptosporidium spp. in dairy calves from the state of São Paulo, Brazil. Parasitol Res 2011; 109(3): 949-951. http://dx.doi.org/10.1007/s00436-011-2336-1. PMid:21472404.

Meireles MV. Cryptosporidium infection in Brazil: implications for veterinary medicine and public health. Rev Bras Parasitol Vet 2010; 19(4): 197-204. http://dx.doi.org/10.1590/s1984-29612010000400002. PMid:21184694.

Nishi L, Bergamasco R, Toledo MJO, Falavigna DLM, Gomes ML, Mota LT, et al. Giardia spp. and Cryptosporidium spp. in the Ivaí Indigenous Land, Brazil. Vector Borne Zoonotic Dis 2009; 9(5): 543-547. http://dx.doi.org/10.1089/vbz.2008.0021. PMid:18945186.

Oliveira JP Fo, Silva DPG, Pacheco MD, Mascarini ML, Ribeiro MG, Alfieri AA, et al. Diarréia em bezerros da raça Nelore criados extensivamente: estudo clínico e etiológico. Pesq Vet Bras 2007; 27(10): 419-424. http://dx.doi.org/10.1590/S0100736X2007001000006.

Oliveira S, Wilmsen MO, Rosalinski-Moraes F. Criptosporidiose em ruminantes: revisão. Pubvet 2012; 6(8): 1307-1312. http:// dx.doi.org/10.22256/pubvet.v16n8.1309. 
Plutzer J, Karanis P. Genetic polymorphism in Cryptosporidium species: an update. Vet Parasito/ 2009; 165(3-4): 187-199. http:// dx.doi.org/10.1016/j.vetpar.2009.07.003. PMid:19660869.

Robert B, Ginter A, Antoine H, Collard A, Coppe P. Diagnosis of bovine cryptosporidiosis by an enzyme-linked immunosorbent assay. Vet Parasitol 1990; 37(1): 1-8. http://dx.doi.org/10.1016/0304-4017(90)90020-c. PMid:2238427.

Ryan U, Fayer R, Xiao L. Cryptosporidium species in humans and animals: current understanding and research needs. Parasitology 2014; 141(13): 1667-1685. http://dx.doi.org/10.1017/S0031182014001085. PMid:25111501.

Ryan U, Hijjawi N, Xiao L. Foodborne cryptosporidiosis. IntJ Parasito/ 2018; 48(1): 1-12. http://dx.doi.org/10.1016/j.ijpara.2017.09.004. PMid:29122606.

Santín M, Trout JM, Xiao L, Zhou L, Greiner E, Fayer R. Prevalence and age-related variation of Cryptosporidium species and genotypes in dairy calves. Vet Parasitol 2004; 122(2): 103-117. http://dx.doi.org/10.1016/j.vetpar.2004.03.020. PMid:15177715.

Sevá AP, Funada MR, Souza SO, Nava A, Richtzenhain LJ, Soares RM. Occurrence and molecular characterization of Cryptosporidium spp. isolated from domestic animals in a rural area surrounding Atlantic dry forest fragments in Teodoro Sampaio municipality, State of São Paulo, Brazil. Rev Bras Parasitol Vet 2010; 19(4): 249-253. http://dx.doi.org/10.1590/s1984-29612010000400011. PMid:21184703.

Silva FA Jr, Carvalho AHO, Rocha CMBM, Guimarães AM. Risk factors associated with the infection by Cryptosporidium spp. and Giardia duodenalis in cattle during their growing phase in dairy herds in the mesoregion of Campo das Vertentes de Minas Gerais, Brazil. Pesq Vet Bras 2011; 31(8): 690-696.

Silva FM, Lopes RS, Araújo-Júnior JP. Identification of Cryptosporidium species and genotypes in dairy cattle in Brazil. Rev Bras Parasitol Vet 2013; 22(1): 22-28. http://dx.doi.org/10.1590/S1984-29612013005000010. PMid:23538500.

Smith RP, Clifton-Hadley FA, Cheney T, Giles M. Prevalence and molecular typing of Cryptosporidium in dairy cattle in England and Wales and examination of potential on- farm transmission routes. Vet Parasitol 2014; 204(3-4): 111-119. http://dx.doi. org/10.1016/j.vetpar.2014.05.022. PMid:24909077.

Thompson RCA, Palmer CS, O'Handley R. The public health and clinical significance of Giardia and Cryptosporidium in domestic animals. Vet J 2008; 177(1): 18-25. http://dx.doi.org/10.1016/j.tvjl.2007.09.022. PMid:18032076.

Thomson S, Hamilton CA, Hope JC, Katzer F, Mabbott NA, Morrison LJ, et al. Bovine cryptosporidiosis: impact, host-parasite interaction and control strategies. Vet Res 2017; 48(1): 42. http://dx.doi.org/10.1186/s13567-017-0447-0. PMid:28800747.

Tiyo R, Souza CZ, Nishi L, Brustolin CF, Ratti BA, Falavigna Guilherme AL. Water from different sources used for the irrigation of vegetables to be marketed: research on Cryptosporidium spp., Giardia spp. and coliforms in Paraná, Brazil. Rev Inst Med Trop São Paulo 2015; 57(4): 333-336. http://dx.doi.org/10.1590/S0036-46652015000400010. PMid:26422158.

Toledo RS, Martins FDC, Ferreira FP, Almeida JC, Ogawa L, Santos HLEPL, et al. Cryptosporidium spp. and Giardia spp. in feces and water and the associated exposure factors on dairy farms. PLoS One 2017; 12(4): e0175311. http://dx.doi.org/10.1371/journal. pone.0175311. PMid:28403147.

Walker M, Leddy K, Hagar E. Effect of combined water potential and temperature stresses on Cryptosporidium parvum oocysts. Appl Environ Microbiol 2001; 67(12): 5526-5529. http://dx.doi.org/10.1128/AEM.67.12.5526-5529.2001. PMid:11722902.

Wells B, Shaw H, Hotchkiss E, Gilray J, Ayton R, Green J, et al. Prevalence, species identification and genotyping Cryptosporidium from livestock and deer in a catchment in the Cairngorms with a history of a contaminated public water supply. Parasit Vectors 2015; 8(1): 66. http://dx.doi.org/10.1186/s13071-015-0684-x. PMid:25650114.

Xiao L, Escalante L, Yang C, Sulaiman I, Escalante AA, Montali RJ, et al. Phylogenetic analysis of Cryptosporidium parasites based on the small-subunit rRNA gene locus. App/ Environ Microbiol 1999; 65(4): 1578-1583. http://dx.doi.org/10.1128/aem.65.4.15781583.1999. PMid:10103253.

Xiao L, Singh A, Limor J, Graczyk TK, Gradus S, Lal A. Molecular characterization of Cryptosporidium oocysts in samples of raw surface water and wastewater. Appl Environ Microbio/ 2001; 67(3): 1097-1101. http://dx.doi.org/10.1128/AEM.67.3.1097-1101.2001. PMid:11229897.

Xiao L. Molecular epidemiology of cryptosporidiosis: an update. Exp Parasito/ 2010; 124(1): 80-89. http://dx.doi.org/10.1016/j. exppara.2009.03.018. PMid:19358845. 